\title{
Nejasné loajality. Způsoby přináležitosti a nepatření migrantů v transnacionálních sociálních polích
}

\author{
Uncertain loyalties. Ways of Belonging and Non-belonging \\ of the Migrants in Transnational Social Fields
}

Radka Klvaňová

\begin{abstract}
The concepts of inclusion and integration are significant parts of both academic and public discourses on migration. These terms and their utilization are rooted in the image of migration as a permanent unidirectional movement between territorially bounded nation state societies. The transnational perspective points to a variety of migrants' social worlds transcending the borders of nation states and plurality of migrants' belongings and it challenges such a conceptualization of inclusion/exclusion of migrating individuals and groups. The paper discusses the re-conceptualization of the process of inclusion/ exclusion of migrants in transnational social fields. It brings attention to the ways of belonging and nonbelonging of the migrants to the multiple communities both "here" and "there" and the ways their belongings are contested and transformed. It argues that the frame of belonging is an important empirical question to avoid normative assumptions of migrants' integration into the receiving nation state container society. Moreover, the transnational perspective raises the question of the link between behavioural participation of the migrants in various social systems both "here" and "there" and felt belonging to various civic communities.
\end{abstract}

KEY WORDS citizenship, migration, inclusion/exclusion of migrants, transnationalism, translocational positionality

\section{Úvod}

Termíny inkluze a exkluze jsou v dnešní době běžnou součástí nejen akademického, ale i politického diskurzu o migraci, kterému dominuje jazyk integrace (Phillips a Saharso 2008). Tyto normativní koncepty, stejně jako další koncepty vztahující se ke společenské soudržnosti, jsou obvykle používány s implicitním předpokladem společnosti národního státu jako jakési jednolité uzavřené nádoby (container society, viz Giddens 1987). Mezistátní migrace je proces, který přispívá k problematizaci ustavených společenských hranic a ke zpochybňování jednoty a stejnorodosti ohraničené společnosti, ale zároveň bývá také používán politickými aktéry $\mathrm{k}$ posilování této jednoty nacionalistickou rétorikou a zdůrazňováním jinakosti migrantů. Transnacionální perspektiva poukazuje na rozmanitost migranty obývaných sociálních světů překračujících hranice národních států a na mnohost přináležitostí migrantů. Nastoluje tak otázku re-konceptualizace procesu inkluze/exkluze migrujících jedinců a skupin.

Sociální studia. Fakulta sociálních studií Masarykovy univerzity, 1/2009. S. 91-107. ISSN 1214-813X. 
V tomto příspěvku se zabývám některými způsoby vymezení inkluze/exkluze migrantů v transnacionální perspektivě. Cílem textu je jednak shrnout kritickou debatu, která se rozvinula okolo konceptu integrace pod vlivem transnacionálního paradigmatu, jednak diskutovat některé sociologické otázky spojené s tématem začleňování migrantů, které transnacionální perspektiva otevírá. Nastiňuji zde možný konceptuální rámec analýzy inkluze/exkluze migrantů v transnacionální perspektivě, ve kterém vycházím z teorie občanské inkluze Jeffreyho Alexandera (Alexander 2006) a konceptu prolínání sociálních kategorií v procesu exkluze (intersectionality, viz např. Anthias 2001, Brah 1996, Davis 2008). Tato teoretická pojetí inkluze a exkluze migrantů propojuji s koncepty transnacionálního sociálního pole a souběžnosti (Basch, Glick Schiller a Szanton Blanc 1994, Levitt a Glick Schiller 2004). Poukazuji na to, že různé pozicionality (positionalities) migrantů v různých občanských sférách v transnacionálním sociálním poli umožňují či naopak zabraňují jejich inkluzi. Je tedy důležité analyzovat, jakými způsoby se tyto pozičnosti ustavují a mění v průběhu migračního procesu v rámci transnacionálních sociálních polí.

Jedná se mi o takové pojetí inkluze/exkluze, které klade důraz na perspektivu sociálních aktérů a jejich subjektivní vnímání začleňování, aniž by přehlíželo jejich zakotvenosti v sítích sociálních vztahů a významů utvářených na kulturní a politické úrovni. Inkluzi/exkluzi migrantů pojímám jako proces - více než výsledný stav inkludovaný/exkludovaný mě tedy zajímají jednání, která vedou k ustavování tohoto stavu. Procesuální pojetí umožňuje analyzovat způsoby, jakými jsou migrující muži a ženy začleňováni a vyčleňováni na různých rovinách v různých sociálních kontextech, které jsou či byly relevantní pro jejich životy. Takto uchopené koncepty inkluze/exkluze odkazují k perspektivě mobility, která umožňuje analyzovat změny v identitách nikoli jako výjimečné, ale jako běžné jevy (Lenz et al. 2002). K otázce kam migranti (ne)patří, se přidávají důležité otázky, jak migranti (ne)patří do různých společenství a jakými způsoby jsou tyto přináležitosti přetvářeny. Nastíněný způsob použití termínů inkluze/exkluze poukazuje na neukončený dialektický charakter procesu změny umístění migrantů $\mathrm{v}$ různých sociálních kontextech $\mathrm{v}$ transnacionálních sociálních polích, jímž migrující jedinci a skupiny procházejí a který je neustále vyjednáván v sociálních interakcích.

\section{Transnacionální sociální pole: prostory inkluzí a exkluzí migrantů}

V sociálních vědách jsou hranice společnosti jako prostoru, kde se odehrává sociální jednání, často vnímány primárně jako hranice národního státu (Beck a Sznaider 2006). Sociální jednání, které jeho hranice překračuje, se tímto ustavuje jako výjimečné, což přispívá ke vnímání migrace a migrantů jako vymykajících se sociálnímu řádu ustavenému v rámci těchto hranic. Transnacionální perspektiva mimo jiné krystalizovala jako kritika slučování konceptů společnosti a národního státu a následného vymezování hranic sociálního života jako hranic národního státu. V rámci migračních studií tak oživila koncept prostorovosti a otázku vztahu fyzického a sociálního prostoru.

Prostorovost jako jedna $\mathrm{z}$ důležitých dimenzí sociálních vztahů, která působí a reguluje jednání sociálních aktérů a zároveň je jimi aktivně utvářena, byla v sociologii ve dvacátém století dlouho opomíjena, v současné době se však stává důležitým prvkem mnohých sociálně-vědních analýz (Musil 2006). Tendenci sociálních vědců přijímat národní stát a jeho 
společnost jako přirozenou formu společenského a politického uspořádání, a tedy i přirozenou jednotku analýzy označují mnozí autoři jako metodologický nacionalismus (napr. Wimmer a Schiller 2002, Favell 2005, Pries 1999, Beck a Sznaider 2006). Ti také kriticky poukazují na to, že tzv. kontejnerový model společnosti, charakteristický zejména pro strukturální funkcionalismus, směřoval $\mathrm{k}$ nahlížení na migraci jako na jednosměrný přesun sociálního aktéra z jednoho relativně uzavřeného a homogenního společenského celku (země původu) do jiného takového prostoru (cílové země). Kontejnerový model, narozdíl od vztahového konceptu společnosti (viz Bourdieu 1998, Giddens 1982), pak logicky přehlíží sociální vztahy a sounáležitosti, které takto vymezené sociální prostory překračují, a znesnadňuje porozumění realitě současných migračních procesů. Podle Priese by měla být mezinárodní migrace analyzována a interpretována s ohledem na měnící se vztah mezi geografickým a sociálním prostorem (Pries 1999: 18). Vlivem globalizace a migrace dochází k rostoucímu rozpojování sociálního a geografického prostoru, přičemž sociální prostor expanduje do více geografických prostorů, a vznikají tak transnacionální sociální prostory (Pries 1999, Faist 2004) nebo transnacionální sociální pole ${ }^{1}$ (Levitt a Glick Schiller 2004)).

Teorie migrace vycházející z predpokladu „přirozené jednoty místa, kultury a identity“ nejsou schopny transnacionální sociální pole „vidět“, a tedy ani teoreticky uchopit (Szaló 2007: 115). Konceptualizace sociálního prostoru vycházející z transnacionálního paradigmatu umožňuje polycentrický pohled (Ley 2004: 155) na životy lidí, jež jsou napojené na různé geografické a sociální prostory. Michael P. Smith píše, že v transnacionálním poli je spíše umožněno myslet globálně a jednat lokálně, myslet transnacionálně a jednat multilokálně, tedy myslet a jednat zároveň na více škálách (multiple scales, Smith 1994). Jednání sociálních aktérů je situováno do mnohovrstevnatého transnacionálního sociálního pole, ${ }^{2}$ jež překračuje geografické, kulturní a politické hranice a zahrnuje jak lidi v pohybu, tak ty, kteří zůstávají fyzicky na jednom místě (Levitt a Glick Schiller 2004). Transnacionální sociální pole jsou utvářena skrze sociální světy migrantů, které se rozprostírají po více či méně vzdálených lokalitách překračujících hranice národních států. $\mathrm{V}$ těchto lokalitách jsou migranti fyzicky, virtuálně či symbolicky př́tomni a tato místa zároveň představují důležitý kontext pro jejich jednání. Transnacionální sociální pole jsou vytvářena na mnoha úrovních: od globálních politických a ekonomických institucí se širokou škálou působnosti až po lokální sociální sítě individuálních aktérů a jejich rodin. Hranice transnacionálních sociálních polí jsou proměnlivé, ohraničené př́ležitostmi a omezeními konkrétních lokalit, v nichž jsou transnacionální praktiky zakotveny (Smith a Guarnizo 1998: 12).

Podle některých autorů a autorek má globální perspektiva tendenci podceňovat význam národního státu pro současné sociální procesy a zakotvuje je v decentralizovaném globálním

V tomto textu dávám přednost termínu transnacionální sociální pole před termínem transnacionální sociální prostor, který je pravděpodobně více užíván v politické teorii transnacionalismu (např. Faist a Ozveren 2004). V teoretickém výkladu však zachovávám terminologii, kterou používají zmiňovaní konkrétní autoři a autorky.

2 Levitt a Glick Schiller definují sociální pole jako souhrn mnohonásobných propojených sítí sociálních vztahů, skrze které dochází k nerovné výměně, uspořádání a proměně myšlenek, praktik a zdrojů (Levitt a Glick Schiller 2004) 
prostoru odpojeném od specifických národně státních teritorií, zatímco transnacionální diskurzy zdůrazňují pokračující důležitosti hranic národních států, státních politik a národních identit (Smith 2001: 3, viz též Ong 1999). Národní státy jsou totiž pro sociální aktéry stále důležitou praktickou kategorií, jež strukturuje jejich vidění světa a sociální jednání. Navíc státy svými politikami jak vůči migrantům, tak vůči ostatním státům a dalším mezinárodním hráčům významně usnadňují či naopak omezují možnosti vytváření a zachovávání transnacionálních aktivit a identit migrantů (Al-Ali a Koser 2002: 5). Transnacionální perspektiva tedy v kontrastu s globální perspektivou bere v úvahu mnohost center, ke kterým se vztahují praktiky a identity migrantů (Smith 2001, Kearney 1995).

Někteř́i autoři a autorky upozorn̆ují na zdánlivý paradox, kdy procesy globalizace a rostoucí migrace jdou ruku v ruce s posilováním nacionalismu jak ve vysílajících, tak v príjímacích zemích (Sackmann, Peters a Faist 2003, Smith a Guarnizo 1998, Westwood a Phizacklea 2000). „V přijímajících městech a státech vznikají hnutí zaměřená na vzkříšení a zhmotnění mytické národní identity jako způsobu zamezení pronikání cizích ,jiných“. Země původu na druhou stranu esencializují své národní identity a rozšiřují je na své národní př́slušníky v cizině s cílem zachovat jejich loajalitu a príliv zdrojů ,zpět domư“““ (Smith a Guarnizo 1998: 10, vlastní překlad). Komunity migrantů pak vytvářejí deteritorializované národní státy, jenž za své občany počítají také lidi, kteří žijí fyzicky rozptýleni na území jiných národních států, ale kteří zůstávají sociálně, kulturně, politicky a často i ekonomicky součástí národního státu, odkud odešli oni nebo jejich rodiče či dokonce prarodiče (Basch, Glick Schiller a Szanton Blanc 1994: 8, viz též Kearney 1995).

\section{Kritické poznámky ke konceptu „integrace“ migrantů}

Koncepty inkluze a exkluze, integrace či začlenění a vyloučení jsou v nejširším pojetí rámovány různými vzájemně se prostupujícími sociálně-politickými a akademickými diskurzy, které se vztahují k sociálním nerovnostem. Koncept sociální inkluze odkazuje především k procesu vypořádání se s jinakostí, jež vytváŕí i legitimizuje sociální nerovnosti materiálního i symbolického charakteru. Jde o proces vyjednávání mezi kandidáty sociální inkluze, tedy těmi, kteří jsou nějakým způsobem rozpoznáváni jako „Jiní“, a těmi, kteří jsou plnoprávnými členy daného společenství (Janků 2003).

Koncept sociální inkluze/exkluze pracuje s představou určité do značné míry homogenní společnosti a od ní oddělených, odlišných skupin. Jeho aplikace na analýzu situace migrantů přináší otázku po specifičnosti postavení migrantů vzhledem ke společenským celkům, ze kterých jsou vylučováni, respektive do kterých jsou začleňováni. Wimmer a Glick Schiller (Wimmer a Schiller 2002: 309-310) uvádí čtyři důvody, které přispěly k ustavení migrantů jakožto zvláštních objektů veřejných politik a vědeckého výzkumu. Podle autorů představují migrující osoby výzvu základním předpokladům projektu budování národních států - politické suverenitě, kulturní a sociální jednotě a teritoriální zakotvenosti. Poválečné sociální vědy pod vlivem ideologie národního státu a funkcionalistického paradigmatu přispěly $\mathrm{k}$ zobrazování migrantů jako potenciálního ohrožení bezpečnosti ohraničené společnosti a k problematickému vnímání migrantů jako kulturně odlišných subjektů nacházejících se na okraji společnosti a vymykajících se normě teritoriální zakotvenosti (Wimmer a Schiller 2002: 311). 
Takové pojetí migrantů se promítá též do teoretických koncepcí jejich začlenění. Paradigma národního státu je reprodukováno nejen médii a politiky, ale také tvưrci opatření zacílených na integraci migrantů skrze financování sociálního výzkumu vázaného na doporučení směřjúících $\mathrm{k}$ vytvoření integrovaného sociálního celku, i sociálními vědci využívajícími ke svému výzkumu statistiky organizované na principu nacionalizované definice populací (Favell 2005).

V následující části chci poukázat na některé předpoklady teoretických konceptů zabývajících se začleňováním migrantů, které formují určitá pojetí procesu migrace a inkluze/exkluze migrantů a znesnadňují porozumění různým aspektům těchto procesů. Kritika z pozice teorií transnacionální migrace směřuje především $\mathrm{k}$ normativním předpokladům ,normální a ,před-migrační 'existence přijímajících zemí jako jednotných, integrovaných a stabilních celkư" (Szaló 2007: 105, 150). Kromě tzv. prijímajících společností jsou do transnacionálních sociálních polí vtaženy další lokality a transnacionální teorie tak problematizují rovněž perspektivu přijímající společnosti, která teoriím začlenění migrantů dominuje. Po krátké reflexi předpokladů těchto konceptů a způsobů, jakými tyto kulturní hegemonie spoutávají a zkreslují pohled na soudobou migraci, se v další části textu pokouším nastínit možné alternativní pohledy na začleňování migrantů inspirované transnacionální perspektivou.

Favell si všímá, že zdaleka nejpoužívanějším konceptem popisujícím vztahy mezi imigranty a prijímajícími společnostmi je $\mathrm{v}$ evropské sociologii pojem integrace, ${ }^{3}$ jež vystihuje evropskou tradici budování národního státu jako vyrovnávání se s kulturní diverzitou Favell 2005: 45). Také pojem integrace je úzce spjat s paradigmatem národního státu, jež jej pojímá jako hlavní organizační jednotku společnosti, jak již bylo řečeno výše. Myšlenka integrace imigrantů je tak ustavena politickým systémem, jenž na rozdíl od jiných sfér společnosti dělí svět na teritoriálně ohraničené prostorové části (Joppke a Morawska 2003: 4). Koncept integrace vede $\mathrm{k}$ představě plného začlenění jedinců, jako ideálního cílového stavu, kterého lze dosáhnout pohybem od vyloučení k začlenění. Tento pohled odráži státní přemýšlení o inkluzi, nebot' státy začleňují jedince jako celé osoby na principu vzájemné výlučnosti (Joppke a Morawska 2003: 4). V logice národních států je od jedince očekávána loajalita vůči právě jednomu společenskému celku vyjádřená skrze institut občanství. Tím jsou definováni inkludovaní občané na jedné straně, a exkludovaní ostatní, tedy neobčané neboli cizinci na straně druhé (Brubaker 1992). Toto duální pojetí obsahuje implicitní normativní předpoklad integrovanosti tzv. prrijímací společnosti a předurčuje migranty jako ty, které je potřeba integrovat při zachování relativní neměnnosti přijímající společnosti. Integrace je tedy v tomto pojetí vnímána především jako úkol migrantů. ${ }^{4}$

3 Na rozdíl od evropské, americká sociologie dává přednost konceptu asimilace (Favell 2005). $\mathrm{V}$ tomto textu dávám přednost použití termínu inkluze, popřípadě začlenění, před hojně užívanými pojmy integrace či inkorporace, ačkoli ani tento termín není bez problematických konotací. Termíny inkorporace (česky doslovně vtělení) a integrace asi nejvíce odkazují k funkcionalistické představě ideální společnosti jako homogenního, ohraničeného celku či „těla“ se všemi problematickými aspekty, které toto pojetí společnosti přináší - viz dále $\mathrm{v}$ textu. $\mathrm{K}$ podrobnější diskuzi terminologie viz Favell (2005).

4 Favell poukazuje na to, jak se dualita integrované přijímací společnosti a neintegrovaných cizinců promítá do výzkumu integrace migrantů. Při zkoumání míry integrace migrantů bývá referenční 
Zdá se, že takovéto pojetí začlenění, jehož stopy stále objevujeme v soudobých výzkumech integrace migrantů, nejenže nereflektuje měnící se podobu migrace a zkušenosti migrantů, na které jako jedny z prvních poukázaly antropoložky Linda Basch, Nina Glick Schiller a Christina Szanton Blanc ve své knize Nations Unbound (Basch, Glick Schiller a Szanton Blanc 1994). Podle Christiana Joppkeho se ale také zásadním zpo̊sobem proměnilo pojetí inkluze a exkluze moderními národními státy, jež byly „,nakaženy univerzalistickou logikou, která vládne v diferencovaných sférách moderní společnosti“ (Joppke 2006: 66). Nejenže různé nestátní společenské sféry přestaly být pod vlivem globalizace spoutané hranicemi národních států, ale i charakter členství v národním státě se díky režimu univerzálních lidských práv proměnil tak, že je možné patřit zároveň do různých národních států. Zabezpečení práv, která byla tradičně zajištována institucí občanství, se do velké míry přesouvá na mezinárodní rovinu, zejména díky konvencím týkajících se ochrany lidských práv či práv migrujících pracovníků a transnacionálních politických formací, jako je např́klad Evropská unie (Soysal 1994).

Liberální národní státy formálně neuplatňují partikularistická kritéria přináležitosti, jedinou legitimní formou exkluze se stává vyloučení na základě individuálních, nikoli skupinových kritérií (Joppke 2006). Tento formální posun od partikularismu národního státu směrem k univerzalizmu lidských práv je pro začleňování migrantů zásadní z hlediska prostupnosti reálných i symbolických hranic a myslitelnosti některých forem inkluze. Přesto např́klad Lydia Morris (2003) poukazuje na to, že konkrétní podoba oprávnění a aplikace práv je obvykle výsledkem historicky zakotveného politického vyjednávání právě na úrovni národního státu. Jsou to často skupinové, nikoli individuální charakteristiky, které implicitně vstupují do vyjednávání inkluze migrantů v rámci systému občanské stratifikace (Morris 2003) a na symbolické úrovni také do formování pocitu přináležitosti migrantů. Formální odmítnutí etnických kritérií přináležitosti v liberálních státech neznamená, že by tyto kategorie vymizely ze sociální praxe v jiných společenských sférách, kde naopak často mají tendenci posilovat na významu (Joppke 2006).

Koncept integrace migrantů vycházející z funkcionalistického pojetí společnosti také naráží na rozpohybovanou realitu současného světa. Obraz společnosti jako teritoriálně zakotveného organismu předurčuje pojetí migrace a vymístění jako odchylku od normy usazenosti (Malkki 1995: 508, Wimmer a Schiller 2002: 310) a koncept integrace tak vychází z představy trvalého usazení, respektive trvalé imigrace. Člověk pohybující se více či méně často mezi dvěma či více lokalitami nebo stěhující se v průběhu života z místa na místo této představě začlenění nevyhovuje. Transnacionální perspektiva se snaží problematizovat statický pohled na migraci jako jednosměrný pohyb mezi dvěma usazenostmi (Tarrius in Morokvasic 2004: 20). Rovněž odmítá vnímat integraci jako proces vedoucí ke zpřetrhání vazeb s ,„původním“ společenstvím a jako výhradní orientaci na přijímací společenství

skupinou obvykle populace občanů daného státu, která je tak implicitně považována za integrovanou (Favell 2005: 55-56). Tento pohled také vysvětluje, proč se sociální vědy při zkoumání inkluze migrantů obvykle zaměřují především na migranty, mnohem méně již však na tzv. hostitelské společnosti, respektive na proces vzájemného vyjednávání a proměny vnímání členství v daných společenských celcích. 
(Basch, Glick Schiller a Szanton Blanc 1994). Jak ukazuje Morokvasic ve svém textu trefně nazvaném „Usazeni v mobilitě“ (Settled in mobility; Morokvasic 2004), člověk může být „usazen“ nejen na určitém teritoriu, ale právě i v pohybu.

Statické pojetí integrace je opět formováno pod vlivem perspektivy přijímajících společností, která ve výzkumu migrace dominuje. Transnacionální perspektiva však vtahuje do centra pozornosti sociálních vědců také další lokality, především tzv. vysílající společnosti. $\mathrm{V}$ těch může být naopak mobilita naprosto běžným každodenním jevem a to do takové míry, že se může stát normativem jako součást přechodových rituálů (Cohen 2004) či běžná životní strategie, jejíž absence může být i znakem neúspěchu. ${ }^{5} \mathrm{Z}$ hlediska sociologického pojetí migrace je důležité, aby ani usazená, ani pohyblivá forma života nebyla přijímána jako norma ${ }^{6}$ (viz např. Szaló 2006), i když v každodenním životě sociálních aktérů tomu tak může být.

Snahy o redefinici konceptu integrace, jenž se stal předmětem trvalé kritiky (např. (Joppke a Morawska 2003, Brubaker 2003, Favell 2005), přinesly komplexnější pohledy na integraci migrantů. Autoři a autorky hovoří o různých dimenzích (Barša 1999, Penninx 2004, Tollarová 2006 ad.) a sférách integrace (Engbersen 2003), stále však převládá funkcionalistický pohled na společnost jako tělo sestávající z funkčně diferenciovaných teritoriálně ohraničených systémů, které nově př́íchozí migranti narušují (Wimmer a Schiller 2002, Joppke a Morawska 2003). Takový pohled na začlenění migrantů přehlíží, že tito jedinci jsou obvykle součástí různých společenství a sociálních systémů, které překračují hranice národních států. Stejně jako nejsou mnohé ekonomické či sociální systémy v současné době svázány hranicemi národních států, nemusí být ani životní svět migrantů nutně ohraničen různými státy či „kontejnerovými“ společnostmi, ale může být žit a představován v rámci různých sociálních sfér či světů zároveň, např́ič prostorem národních států v transnacionálních sociálních polích (Levitt a Glick Schiller 2004).

To ovšem neznamená, že by kategorie praxe ustavené národním státem neměly v každodenním životě migrantů a v jejich sebepojetí skutečnou relevanci. Tyto kategorie naopak dávají sociálním aktérům smysl pro sociální řád a jsou jimi používány pro základní orientaci ve společnosti. Životy migrantů nejsou zcela odtrženy od konkrétních národních států, nebot' stále významně ovlivňují - omezují i umožňují - jejich jednání a identity (Smith 2001). Kritika z pozice teorií transnacionální migrace však směřuje zejména $\mathrm{k}$ tomu, že by to, jakým způsobem sociální aktéři chápou a používají kategorie ustavené národním státem, mělo být reflektováno sociálními vědci a samo o sobě učiněno předmětem výzkumu, nikoli považováno za předem dané. Transnacionální perspektiva tak zvýrazňuje hledisko sociálních aktérů, kterých se změny v jejich začlenění týkají, tedy zejména migrantů a jejich rodin, a zkoumá,

5 Tuto situaci často popisují např́klad pracovní migranti ze Zakarpatské Ukrajiny. Tento region je charakteristický dlouhou historií dočasné pracovní migrace svých obyvatel, kteří se nad rozcestovanou realitou každodenního života svých rodin a spoluobyvatel nijak nepozastavují. Podobně začíná norma mobility pronikat do života mladých lidí např́íklad v rámci Evropské unie prostřednictvím různých studentských a mládežnických výměnných programů.

6 Graeme Hugo (2007) poukazuje na to, jak se paradigma trvalé imigrace promítá do migračních statistik, které sbírají zejména data o trvale přestěhovaných. Paradigma trvalé imigrace se skrze tato data reprodukuje, což znesnadňuje uchopení rozrůzňujících se forem migrace. 
jakým způsobem vstupují kategorie vytvořené národním státem či jiné alternativy do vyjednávání přináležitosti migrantů k různým společenským celkům.

\section{Souběžná a mnohonásobná začlenění migrantů}

Problém inkluze/exkluze migrantů je neoddělitelně spjat s otázkou, co znamená být začleněn ve věku migrace (Castles a Miller 1998). Joppke a Morawska (2003) navrhují diferenciované pojetí inkluze/exkluze migrantů, které stírá normativní rozlišování mezi „domácími“ a „imigranty“. Termín „neintegrovaný imigrant“ označují za strukturální nemožnost a navrhují, že z hlediska decentralizovaného pohledu na moderní společnost je možné vnímat začlenění migrantů jako aktérů mnoha specifických a vzájemně propojených polí či systémů. „Imigranti jsou stejně jako kdokoli jiný vždy zároveň exkludováni i inkludováni, exkludováni jako celistvé osobnosti a inkludováni jako sektoroví hráči nebo činitelé se specifickými přednostmi a habituálními dispozicemi v rámci určitých polí nebo systémů (...) imigranti jsou konceptuálně asimilováni s jinými jedinci a uskupeními s podobnými pozicemi..." (Joppke a Morawska 2003: 3). Takové pojetí začlenění migrantů přináší otázky po mnohonásobných inkluzích a exkluzích $\mathrm{v}$ rámci různých sociálních systémů s různou mírou teritorializace: některé jsou pevně lokálně ukotveny, některé překračují hranice národních států, jiné jsou deteritorializované, tvořené sociálními sítěmi. Z hlediska sociálních aktérů zaměřuje transnacionální perspektiva pozornost na to, jakým způsobem se migrující souběžně zapojují do různých sociálních systémů $\mathrm{v}$ rámci transnacionálního sociálního pole, zejména ve svých původních i nových domovech.

Peggy Levitt ve svém textu „Keeping Feet in Both Worlds“ (2003) představuje případ mladého muže z městečka Bodeli v Indii, jenž se přestěhoval s rodinou do Spojených států. Jeho životní svět se rozprostírá jak v místě původu, tak v místě nového domova. Začlenil se do hlavního proudu amerického ekonomického života, kde však nemá zájem participovat na kulturních a náboženských institucích. Paralelně se skrze podnikatelské a rituální aktivity účastní ekonomického i náboženského života původní komunity v Bodeli. Po třech letech života v Americe kombinuje strategii selektivní asimilace a transnacionalismu, jež umožňují jeho sociální mobilitu v původním i novém domově (Levitt 2003: 191).

Transnacionální perspektiva dodává pojmům inkluze/exkluze migrantů na komplexnosti díky klíčovému konceptu souběžnosti (Levitt a Glick Schiller 2004). Klasické teorie migrace a inkluze migrantů pojímaly jejich začlenění v novém domově a jejich transnacionální zapojení jako vzájemně se vylučující, protikladné formy sociální participace a přináležitosti. Transnacionální perspektiva zpochybňuje „,bud', anebo“ logiku nacionalismu a nahrazuje ji logikou „tak i tak“ (Beck a Sznaider 2006: 14), která zaměřuje pozornost na souběžnost začlenění migrantů. Transnacionální perspektiva a diferencované pojetí inkluze odvádí pozornost od otázky, zda jsou začleněni či vyloučeni, k otázce jak.

Mladá migrantka z Ukrajiny, která již téměř deset let pracuje v Praze a zároveň pravidelně několikrát do roka jezdí do svého původního domova, popsala svůj život rozdělený mezi „tady“ a „tam“ takto: „...doma máte všecko, tady nemáte skoro nic. Tady máte jenom ,práce a domů‘, no a doma máte 
úplně všecko. Takže doma jenom žijete a tady jenom pracujete.“ Zatímco život v Praze je popisován z hlediska produkce, život v ukrajinském městě, odkud pochází, je v jejím vyprávění reprezentován jako místo spotřeby, místo, kde je možné život plnohodnotně žít a realizovat své tužby. To by ovšem nebylo možné bez práce v Praze (FEMAGE, 2006).

Transnacionální migranti a migrantky se skrze migraci začleňují v různých sociálních systémech (napřr. ekonomika, rodina, sousedství, sféra konzumu) v transnacionálních sociálních polích, která se v jejich životech vzájemně doplňují a ustavují. Jejich životní svět je rozprostřen po různých více či méně vzdálených lokalitách, protože ani jeden z jejich domovů neumožňuje plně naplnit jejich cíle a očekávání (Fouron 2003). Svojí mobilitou, skrze kterou organizují svůj život tak, že spoléhají na sociální systémy překračující hranice národních států, zpochybňují národně-státní koncepci unikátního občanství.

Ruba Salih ve své studii (2001) popisuje komplementární transnacionální životy marockých migrantek v Itálii. Orientace jak na nové, tak původní domovy představuje pro tyto ženy způsob, jak optimalizovat zdroje a utvářet své sociální identity. V jejich životech se vzájemně doplňují různé, stejně důležité symbolické a materiální zdroje pocházející z obou lokalit (Salih 2001).

Diferencovaná inkluze ${ }^{7}$ Joppkeho a Morawské odkazuje k pojetí inkluze jako behaviorální participace v různých společenských sférách. Je však otázkou, do jaké míry lze začlenění migrantů do různých společenství redukovat na jejich participaci v různých sociálních systémech v transnacionálních sociálních polích. Další důležitou dimenzí začlenění je i rovina přináležitosti (belonging), kterou Jeffrey Alexander považuje ve své koncepci inkluze okrajových skupin za zásadní (Alexander 1988).

Termín inkluze byl v sociologii vždy spojen s moderní ideou univerzálního lidství, která je reprezentována ideálem občanské komunity (Alexander 2007). Alexander vymezuje občanskou sféru jako sféru solidarity, ve které je kulturně definována a institucionálně vynucována určitá forma univerzalizujícího společenství (2006: 31). Ta je - navzdory modernímu požadavku univerzální rovnosti legitimizující nároky na inkluzi - silně stratifikovaná na základě různých partikularistických charakteristik, jež pronikají do občanské sféry z jiných, neobčanských sfér. Právě zde se projevuje kontradiktorní povaha domněle univerzální občanské společnosti, která je ve skutečnosti fragmentovaná neboli rozdělená sociálními rozdíly na základě etnicity, „rasy“, náboženství, genderu a třídy (Alexander 2006: 9). Je to právě občanská sféra, ve které je vyjednávána inkluze/exkluze různých okrajových skupin skrze jejich symbolické reprezentace, které Alexander označuje jako občanské a neobčanské kódy. Sounáležitost je vždy formována ve vztahu k ,Jiným“ a artikulována skrze jazyk neobčanskosti (uncivility) „Jiných“ (ibid: 50). Hranice ústřední skupiny jsou vyjednávány v nejrůznějších prostředích a diskurzech a zakoušeny v každodenním životě jak těmi, kdo jsou uvnitr̆, tak těmi, kdo jsou vně daného představovaného společenství. Definice členství tak zahrnuje konkrétní představy o tom, jaké varianty kategorií identity (etnicity, ,rasy“, náboženství, genderu a třídy atd.) a jednání s nimi spojených vykazují ti, kteří patří k danému společenství.

Použití termínu „diferencovaná inkluze“ pro analytické pojetí inkluze Joppkeho a Morawské by nemělo být zaměněno za politický model „diferencované exkluze“, který je v Evropě spojován s politikami některých států vůči hostujícím dělníkům (viz např. Castles \& Davidson 2000). 
Alexander definuje inkluzi jako změnu ve statusu solidarity okrajových skupin, přičemž klade důraz na fenomenologickou rovinu inkluze jako pocit’ované přináležitosti, nikoli ,jen“ behaviorální participace (Alexander 1988). Participace v různých sociálních institucích konkrétního společenství nutně nemusí přinášet začlenění v občanské sféře. To otevírá otázku, jak se v souvislosti s proměnami participace migrantů v různých sociálních systémech v rámci transnacionálních sociálních polí mění pocit přináležitosti k různým občanským komunitám.

Strukturální pojetí inkluze migrantů jako behaviorální participace Joppkeho a Morawské sice dekonstruuje pronikání politického projektu integrace migrantů do sociologického výzkumu, neposkytuje však účinný analytický rámec pro zkoumání nerovných pozic migrantů a nemigrantů zakoušených $\mathrm{v}$ každodenním životě především $\mathrm{v}$ důsledku přetrvávající politické organizace populací do národních států. Teze o post-nacionálním občanství (Soysal 1994) sice poukazuje na měnící se podoby občanského začlenění v globalizovaném světě, je však také důležité sledovat, jak tyto pohyby mění hranice ústředních solidarit. Změny související s měnícím se objemem i povahou migrování narušují moderní koncepci členství v národním státě postavené na exkluzivních vazbách loajality a sounáležitosti. Ve snaze o sebezáchovu některé státy na tyto trendy reagují redefinicí členství, která však, jak mnozí autoři a autorky poukazují, nevede k denacionalizaci, ale zůstává součástí projektu budování národního státu ${ }^{8}$ (Basch, Glick Schiller a Szanton Blanc 1994, Westwood a Phizacklea 2000, Sackmann, Peters a Faist 2003).

Ideálně-typický transnacionální subjekt zapadá do definice členství jak „tady“, tak „tam“, respektive v obou či více lokalitách působnosti migrantů. ${ }^{9}$ Migranti, kteří chtějí dát najevo svoji přináležitost ke svým původním i novým domovům, tak musí volit různé strategie jednání, kterými normalizují své jednání „tady“ i „tam“. Z hlediska transnacionálního subjektu vyžaduje tato vícenásobná přináležitost schopnost „přepínáni““ mezi habity čili performanci kulturních kódů, které signalizují přináležitost $\mathrm{k}$ oběma společenstvím. $\mathrm{Z}$ hlediska definic členství v ústředních skupinách je kličové, že tyto definice nejsou v zásadním rozporu. $\mathrm{V}$ realitě je však spíše možné pozorovat různé způsoby přináležitosti a nepatření $\mathrm{k}$ různě ohraničeným ústředním či okrajovým skupinám, jak „tady“, tak „tam“, tedy v nových i původních lokalitách působnosti migrantů, a $\mathrm{k}$ tomu, jak jsou tyto přináležitosti sjednávány a zpochybňovány. To, do jaké občanské komunity se migrující začleňují, se spíše než jako normativní předpoklad (tj. národní stát) jeví jako empirická otázka, která může odhalit různé roviny přináležitosti $\mathrm{k}$ různým občanským společenstvím $\mathrm{v}$ transnacionálních sociálních polích. Ptáme se, na jakou inkluzi migranti aspirují - kam se chtějí či nechtějí začlenit - a také kam jsou začleňováni či kde je jim různými institucionálními praktikami inkluze odpírána.

8 Exemplárním příkladem narušení konceptu moderního občanství je institut dvojího občanství, který je sice mnoha státy stále udělován spíše ve výjimečných př́ípadech, tyto změny ovšem dobře ilustruje.

9 Článek se zaměřuje na otázku začleňování migrantů v transnacionální perspektivě. Z hlediska sociologické teorie lze však podobným způsobem uvažovat i o začleňování nemigrantů, tedy sociálních aktérů, kteří zůstávají fyzicky na jednom místě, ale i přesto mohou být zapojeni v transnacionálních sociálních polích (viz Henig v tomto čísle Sociálních studii) a zároveň různými způsoby patřit či nepatřit $\mathrm{k}$ různým společenstvím. 


\section{Proměny přináležitostí migrantů: zpưsoby přináležitosti a nepatření10 v transnacionálních sociálních polích}

Kritéria přináležitosti k občanským společenstvím jsou otázkou vyjednávání mezi různými mocenskými skupinami - genderovými, tř́́dními a etnickými (Lenz et al. 2002). Migranti zaujímají různé sociální pozice $\mathrm{v}$ rámci sociálních vztahů, skrze které dochází $\mathrm{k}$ vyjednávání přináležitosti. Tyto pozice zahrnují jednak sebe-identifikaci migrantů $i$ jejich identifikaci ze strany druhých (Brubaker 2004). Floya Anthias (2002) píše v této souvislosti o pozicionalitě̌ ${ }^{11}$ (positionality) zahrnující jak sociální pozici jedince v sociální strukturè, tak sociální umístění odkazující k jednání a významům, skrze které jsou různé identifikace praktikovány a interpretovány. Její koncept translokační pozicionality (translocational positionality) se pak snaží uchopit komplexní protínání různých kategorií identity v procesu vyjednávání začlenění a také situační charakter tohoto vyjednávání. V různých kontextech jsou tak zvýznamňovány či upozad’ovány různé aspekty pozicionality sociálních aktérů (Anthias 2002). Koncept translokační pozicionality umožňuje analyzovat inkluzi migrantů jako subjektů mnohonásobné kategorizace: jako členů etnických či náboženských skupin, tř́íd či nositelů genderových identit. Skrze koncept translokační pozicionality lze zároveň uchopit i proces vytváření hranic stejnosti a odlišnosti a proces konstrukce hierarchických pozic (Anthias 2002).

$\mathrm{V}$ rámci transnacionálních sociálních polí jsou migranti různě umístěni (positioned) vzhledem ke společenstvím, která jsou relevantní pro jejich životy, a tyto pozicionality přinášejí různý potenciál pro jejich inkluzi. Tato společenství netvoř́ jen národní státy, ale také různá transnacionální, regionální či lokální společenství přináležitosti. Skrze proces migrace může docházet $\mathrm{k}$ proměně statusu přináležitosti migrantů jak v původních, tak nových lokalitách působnosti migrantů. Akt migrace, respektive proces, skrze který jsou sociální aktéri rozpoznáni jako migranti, tak ovlivňuje jejich občanské kapacity (Alexander 2006) neboli možnosti začlenění vzhledem $\mathrm{k}$ oběma (či více) společenstvím. V každém z kontextů pak mohou být zvýznamňovány různé aspekty jejich pozicionality, které jsou formovány ve vzájemné interakci obou kontextů - nového a původního domova - či dalších polí. Přináležitosti $\mathrm{k}$ novému i původnímu domovu jsou tak souběžně utvářeny a přetvářeny s tím, jak jsou neustále pod vlivem migrace a transnacionalizačních procesů redefinovány podmínky členství vymezující, kdo a za jakých okolností může k danému společenství patřit a kdo nikoli.

$* * *$

V následující části ilustruji výše naznačené konceptuální rámce empirickými př́klady z vlastního výzkumu ${ }^{12}$ i z dalších dostupných dat. Vycházím z biografických vyprávění

10 Výrazy „přináležitosti“ a „nepatření“ jsou ekvivalenty anglických termínů „,belonging“ a „non-belonging.“

11 Původní záměr přeložit tento termín výrazem ,pozičnost“ byl po konzultaci Barkerova Slovníku kulturálních studií (Barker 2006) změněn ve prospěch v českém kontextu používanějšího překladu „pozicionalita“.

12 Citace $\mathrm{v}$ textu pochází z kvalitativních rozhovorů (zejména biografických vyprávění migranti̊) s první generací migranti̊ ze tří zemí bývalého Sovětského svazu - Běloruska, Ruska a Ukrajiny -, kteří žijí dlouhodobě ve dvou městech České republiky - v Praze a v Brně. Výzkum „Inkluze/exkluze migrantů v transnacionální perspektivě“ probíhá od roku 2007 v rámci Institutu pro 
migrantů a migrantek, jejichž životy různými zpo̊soby překračují hranice národních států, konkrétně Česka, Běloruska, Ukrajiny a Ruska. Níže uvedené příklady především dokumentují některé podoby vyjednávání přináležitosti a nepatření migrantů na různých rovinách sociálních a transnacionálních polí. Nekladou si tedy nárok na reprezentativnost a zobecnění poznatků vzhledem ke zkoumané skupině migrantů a procesu jejich inkluze/exkluze.

$\mathrm{K}$ formování pocitu přináležitosti a nepatření migrantů k různým společenstvím dochází v nejrůznějších každodenních situacích. Biografická vyprávění migrantů zvýznamňují některé události, ve kterých se migranti umíst'ují a jsou umistováni v sociálním a transnacionálním prostoru, a umožňují nahlédnout zpơsoby vyjednávání přináležitosti a nepatření. Zároveň, jak upozorňuje Anthias (2002), tato vyprávění a identifikace jsou vždy situačně lokalizována, což odhaluje různá napětí a nejednoznačnosti, které formování pocitu přináležitosti doprovází. Z hlediska konceptu translokační pozicionality je při čtení a interpretaci úryvků z vyprávění migrantů důležité reflektovat mimo jiné daný sociální a politický kontext i kontext výzkumných rozhovorů, jež se odehrávaly mezi výzkumnicí, vnímanou jako „zástupkyní“ české ústřední skupiny, a výzkumnými partnery a partnerkami, jakožto „členy“ okrajových skupin.

Vyprávění migrantů odhaluje různé podoby napětí mezi patřením a nepatřením $\mathrm{k}$ různým společenstvím sounáležitosti. Zajímavými událostmi, které toto napětí zvýrazňují, jsou „návraty domů“, jež často vedou migranty k reflexi povahy jejich vztahu k původnímu a novému domovu. Návraty do původních domovi̊ představují důležité situace, ve kterých si migranti uvědomují změny přináležitosti (Strauss 1997: 95-96, Long a Oxfeld 2004). Migrantka Ivana žijící jedenáct let v Brně vypráví o svých pravidelných cestách do svého původního domova $\mathrm{v}$ malém městečku na jihu Běloruska, které zpravidla podniká i s manželem a dcerou jedenkrát do roka:

I: Nevím, do Běloruska bych se nechtěla vracet, tedy zatím, nevím, co bude, ale zatím ne. I ten náš prezident, není tam svoboda, nevím. Lidé tam - když tam přijedeme jak svobodní lidé, třeba řekneme nějaký vtip, hned ř́kají: „Potichu! To nemůžeš tak nahlas.“ Proč? (...)

Takže, já nevím, já sem jedu jak domů. Já tam do Běloruska jedu jak na návštěvu. (...)

RK: A jak se tam citite, když tam přijedete na návštěvu?

I: Nevím. Já osobně se tam dobře necítím. Protože kamarádi, kteří tam zůstali, kteří s námi nechtěli, které jsme zvali třeba sem, at' s námi jedou, tak vždycky našli nějaké výmluvy - a zkuste to tam, a pak uvidíme - a pak nejeli, tak ted' nám závidí. Oni nedosáhnou na tu naši úroveň ani za deset let, takže to je pak špatný, když pomlouvají a tak. (Ivana, 35 let, 17.10. 2008)

Její výpověd' ilustruje proměnu přináležitosti, jež je typická pro migranty, jejichž projekt přestěhování se proměňuje $\mathrm{z}$ dočasného na trvalý a $\mathrm{z}$,návratů domů“ se stávají návštěvy. Pocit nepatření do původního domova se projevuje v různých každodenních interakcích s těmi, kdo zde zůstali. Migranti je nejčastěji popisují jako změny myšlení, chování, tělesnosti a vzhledu, jako je způsob chůze či oblékání, jež naznačují změnu habitu, který je vyděluje z původního společenství. Ivana zvýznamňuje změnu trrídního postavení v rámci

výzkum reprodukce a integrace společnosti. Jména všech informátorů citovaných v textu byla změněna. 
původního společenství a odlišné pojetí (svobodného) jednání ve veřejném prostoru, které přináší pocit, že už ne tak zcela patří do původního domova, a formuje zároveň pocit přináležitosti k novému domovu. Jiná migrantka ze Zakarpatské Ukrajiny popisuje, jak odchýlení se od patriarchálních genderových norem, platných v původním domově, signalizuje při návštěvách její odlišnost.

Když príjedu domů jenom v džínech, tak se lidi diví, protože upravené ženy, to je na Ukrajině základ. Kamarádky se mi smějí, že řeknu svůj názor. Říkají: „Jsi typická Češka!“‘. Protože mám jiné uvažování. Na Ukrajině se ženské musí postarat o chlapy (...) Když potkám stejně starou Ukrajinku, tak já pro ni nejsem ženská (Jana, 30 let, 16.6.2008).

$\mathrm{V}$ interakci s těmi, kdo zůstali v původních domovech, jsou zvýznamňovány změny $\mathrm{v}$ jednání migrantů, jež jsou jakoby nakaženy sociálním řádem nových lokalit působnosti migrantů. Janiny změny v jednání jsou těmi, kdo zůstali v původním domově, interpretovány jako „počeštěni“", které v logice nacionalistického symbolického řádu znamenají „zradu“ původní kultury, a tedy nepatření k etnizované občanské komunitě, jež mimo jiné stanovuje, co to znamená být normální či správnou ženou. ${ }^{13}$

Kontrastní vůči tomu je vyprávění Věry, pro kterou návraty do původního domova v Kyjevě i po deseti letech života stráveného převážně v Brně znamenají spíše potvrzení své přináležitosti k původnímu domovu a nepatření do nového domova. Proces formování přináležitosti je $\mathrm{v}$ jejím vyprávění spojen jednak se změnou sociálního statusu, jednak s odlišnými společenskými normami týkajícími se mezilidských vztahů. Ztráta prestiže spojené se zaměstnáním manžela $\mathrm{v}$ ukrajinském státním podniku a každodenní opory $\mathrm{v}$ podobě prátelských a sousedských vazeb a jejich znovunalézání při návratech do původního domova - to jsou některé události, které vstupují do vyjednávání přináležitosti k původnímu a nepatření k novému domovu. Ve vyprávění Věry je navíc zvýznamňován také věk její a jejího manžela, ve kterém se i s dvěma dospívajícími dětmi přestěhovali do Brna.

V: ... bylo to těžké, protože manžel i děti tam všechno nechali. Můj manžel měl moc dobrou práci. Dříve za Sovětského svazu pracoval ve státním podniku a byl ředitelem transportní firmy, která za všechno odpovídala po celé Ukrajině. Takže když přijel sem, bylo to pro něho šokující, zaprvé (po přestěhování manžel pracoval několik let jako stavební dělník, pozn. R.K.). A víte, co znamená pro nás, dospělé lidi, nechat tam kamarády? U nás trochu ... tady máte jiný styl života a vůbec hodnoty, a u nás kamarádství ... Třeba já jsem klidně mohla s mojí sousedkou nechat svoje děti, když byly nemocné. My jsme měly stejně staré děcka, když její dítě bylo nemocné, hned byla nemocná i dcera, takže my jsme si nebraly obě dvě nemocenskou a ona mi důvěřovala, nechala u mě svoje dítě, když mělo horečku (...) nebo třeba když my přijedeme ted' domů, tak já budu vědět, že sousedi, oni ví, že máme za sebou dlouhou cestu, 36 hodin vlakem, to je moc daleko, takže oni nachystají jídlo a všechno. My jenom otevřeme dveře a oni už nám všechno donesou (...) my jsme tady už hodně dlouho, skoro už deset let a to je stále stejné (...) tady jsem se s tím ale nesetkala. Tady jsem se snažila, my bydlíme $\mathrm{v}$ jednom domě, kde je sedm nebo osm bytů, a docela se zdravíme, skamarádíme... a já jsem

13 Z hlediska narativních strategií lze navíc podobné příběhy migrantů interpretovat jako potvrzování jejich přináležitosti k novému domovu a vytváření „,identity integrace“ (Klvačová 2006a). 
pozvala k sobě sousedku na kávu, udělala jsem nějaký dort, nějaký piroh, pozvala jsem ji na kávu a ona ke mně přišla se svým šálkem kávy! (Věra, 44 let, FEMAGE, 2006)

Způsoby nepatření do původního domova naznačené v př́padě Jany a Ivany zároveň však neznamenají, že by migranti zcela ztratili přináležitost k původnímu společenství sounáležitosti a plně se identifikovali se svými novými domovy. Na jiném místě svého vyprávění vyjadřuje Ivana svoji přináležitost $\mathrm{k}$ běloruské imaginární komunitě skrze metaforu sportovního fanouškovství. ${ }^{14}$ Její citace zároveň reflektuje předpoklad neměnnosti a danosti vlastní etnokulturní identity, která ji váže k původní občanské komunitě.

\section{RK: A změnil se nějak Váš vztah k Bělorusku...?}

I: Tak, to ne, to ne. Nevím. Tak vždycky, když se díváme na televizi a je třeba nějaký hokej nebo fotbal a je tam Bělorusko, např́iklad Bělorusko-Česko, tak fandíme Bělorusku. To se asi nezmění (smích). (...) A dcera vždycky ř́íá: „mamko, kdo hraje dneska?““ Ŕíkám: „Rusko-Česko“. „At’ ti Rusi vyhrají.“ Já říkám: „Proč?““ „Protože Češi jsou pak nafoukaní (...) Ř́íkají: ,Tak co, Anno (dcera), co ten fotbal, co ten hokej?‘ At’ Rusi vyhrají. Ona to bere jako dítě spíš, ale je pravda, že když hrají naši, tak naši jsou Bělorusi. A když hrálo třeba Slovensko a Česko, tak určitě budeme fandit Česku. (Ivana, 35 let, 17.10. 2008)

Poslední část citace z Ivanina vyprávění poukazuje nejen na dvojí přináležitost, jak $\mathrm{k}$ původnímu, tak k novému společenství, ale také na určitou situační hierarchizaci těchto solidarit.

Jan, migrant ze Zakarpatské Ukrajiny, vypráví o tom, jak si s každou cestou do původního domova uvědomuje své odcizení, nebot' jeho pohled na svět se změnil a interakce s přáteli mu přináší neprŕijemné pocity. Sám sebe popisuje někde „mezi“, v transnacionálním prostoru mezi původním a novým domovem. Pocit nepatření ,ani tady, ani tam“, jenž je často popisován transnacionálními teoriemi (srovnej Al-Ali 2002: 113, Fouron 2003), vychází z předpokladu plného začlenění, podle kterého by měl člověk plně patřit k jednomu domovu. Vyprávění Jana však zároveň možnost jeho dosažení zpochybňuje.

Tady pořád to bude takové... nebude to nikdy takový pocit domova. I kdybych tady bydlel nevím kolik roků, něco bude pořád daleko, něco maličkého, ale nebude to úplné. A zase na Ukrajině, v Chustu třeba, tam taky už nejsem doma, protože jsem tam jak cizí. Nikdo mi nerozumí, ta filosofie nebo názory nebo co se prostě změnilo. Jsou tak odlišní, že už s nimi ani normálně nemůžu mluvit (smích). Takže patřím, ani nevím, kam patřím. (Jan, 40 let, 6.8.2007)

Vrátíme-li se nyní k úryvku z Ivanina vyprávění o sportovním fanouškovství, je možné si všimnout také další roviny formování přináležitosti, která je charakteristická pro značnou část migrantů z některých zemí bývalého Sovětského svazu. Reprezentace těchto migrantů ve veřejném diskurzu pracují s kategorií „Rusové“, s nimiž se setkává většina rusky mluvících migrantů žijících v Česku, především ta z Běloruska, Ruské federace a Ukrajiny. Analýza vyprávění migrantů z těchto tří zemí ukazuje, že tento referenční rámec, jenž bychom mohli označit za transnacionální, mnozí migranti sdílejí, přičemž v různých kontextech se $\mathrm{s}$ ním

14 Podrobněji o dělených loajalitách v případě sportovního fanouškovství Marada v tomto čísle Sociálních studií. 
bud' ztotožňují, či se od něj distancují. Vyprávění Věry ilustruje, jakých významů nabývá kategorie „Rusovée“ v českém i ukrajinském (post-sovětském) kontextu a jaká napětí provází vyjednávání etnizovaných identit, jejichž hranice jsou nejasné. Věra v tomto úryvku popisuje své rozsáhlé zkušenosti se slovními útoky na svého syna, kterých se mu v Česku dostávalo od učitelů a spolužáků s poukazem na historické události z období sovětského imperialismu. Tyto zkušenosti jsou migranty z Ruska, Ukrajiny a Běloruska široce sdílené (srov. Klvačová 2006b).

Nechápu, jak to může někdo vyčítat mému klukovi. Ted’ už jim syn řekne: „víte co, já jsem Ukrajinec. Sovětský svaz, jasně, vy se zlobíte za šedesátý osmý rok, ale tenkrát to byly země Varšavské smlouvy. Bylo to NATO na jedné straně a země Varšavské smlouvy na druhé straně, takže tam byli všichni. Nevím, kdo tam vládl, a jestli vládlo Rusko, tak já jsem z Ukrajiny, my jsme byli také hodně dlouho pod Rusy.“ (...) Já jsem mu pořád říkala: „musíš vydržet.“ Protože i u nás jsou takoví nacionalisti, jenom ukrajinština, kteří psali na zdi „Rusové pryč a ,Ivane, jdi domů‘ Ale já ř́íám, my jsme Ukrajina a Rusko, na Ukrajině je polovina ruských lidí, protože my jsme tam všichni propojení, provdaly jsme se nebo někdo tam jel pracovat nebo... Já mám sestřenice na severu Ruska a tatínkův bratr žije v Kaliningradu, to je taky Rusko. Žije tam s celou rodinou, a i když je Ukrajinec, tak to je jedno, vzal si ruské občanství. Ale zase oni tam bydlí celá rodina už dlouho, takže co já mám říct...? Jak bych se mohla chovat k někomu špatně, když já mám celou rodinu rozprášenou po celém světě? (Věra, 44 let, FEMAGE, 2006)

Věra se na jedné straně distancuje od ruské identity, jež je v českém kontextu značně stigmatizovaná, na druhé straně poukazuje na to, že stanovit hranice přináležitosti je složité a spíše se zdráhá jednoznačně se přiklonit k pevně vymezené etnokulturní imaginární komunitě.

Další transnacionální rovinou přináležitosti, jež se objevuje jako relevantní při vyjednání začlenění migrantů ve výše vymezeném kontextu, je imaginární společenství sounáležitosti označované jako slovanské. Slovanství má pro migranty z Běloruska, Ruska a Ukrajiny v českém kontextu vysoký inkluzivní potenciál, jenž čerpá z představ o „,kulturní blízkosti““ „podobné mentalitě“ či ,př́íbuznosti“ daných imaginárních komunit. Tato transnacionální etnokulturní imaginární komunita zprostředkovává migrantům vyjádření dvojí přináležitost jak k původnímu, tak k novému domovu. Diskurz slovanství vymezuje hranice stejnosti či podobnosti, které zároveň určují, kdo do této imaginární komunity nepatří - migranti z neslovanských zemí.

Přináležitosti migrantů jsou formovány skrze klasifikující „Druhé“, kteří se nacházejí v transnacionálních sociálních polích, zahrnujících jak původní, tak nové domovy migrantů a někdy i další místa (Szaló 2007: 105). Ve světě organizovaném na principu národních států zůstává i přes značnou mobilitu a hybridizaci identit etnicita či př́slušnost k národnímu státu jedním z klíčových kritérií přináležitosti. Pod vlivem ideologie nacionalismu je v přijímajících společnostech zvýznamňována především etnokulturní identita migrantů. Ve výše zmíněných př́kladech jsem poukázala na různá napětí, které doprovází vyjednávání přináležitosti migrantů v symbolickém řádu nacionalismu předpokládající exkluzivní vazby sounáležitosti. 


\section{Závěr}

V tomto článku jsem se věnovala promýšlení procesu inkluze/exkluze migrantů v transnacionální perspektivě. Transnacionální teorie zpochybňují vzájemně se vylučující začlenění migrantů, kteří dnes často nějakým způsobem přináleží zároveň ke dvěma i více společenstvím v transnacionálních sociálních polích. Důležitou výchozí empirickou otázkou při zkoumání inkluze/exkluze migrantů tedy je prozkoumání toho, na jakých rovinách v transnacionálních sociálních polích se migranti začleňují. Takto postavená otázka umožňuje vyrovnat se s problémem zamlčeného předpokladu inkluze migrantů do ohraničeného společenství přijímajícího národního státu, a může odhalit rozmanité roviny přináležitosti k různým společenstvím v transnacionálních sociálních polích.

U mnohovrstevnatého teoretického konceptu inkluze/exkluze migrantů jsem se zaměřila především na fenomenologickou rovinu přináležitosti k různým imaginárním komunitám $\mathrm{v}$ transnacionálních sociálních polích. V souvislosti s proměnou začlenění migrantů navrhuji mluvit o různých způsobech přináležitosti a nepatření migrantů k původním i novým domovům, jež se formují v různých kontextech a jsou proměnlivé v čase i prostoru a v závislosti na typu sociálních interakcí. Poukazuji tak na neukončený dialektický charakter procesu změny umístění migrujících jedinců v různých sociálních a transnacionálních polích, která jsou neustále vyjednávána. Promýšlení různých způsobů sounáležitosti a nepatření naznačuje různá napětí a nejednoznačnosti, které formování přináležitosti doprovází. Ve vyjednávání přináležitostí či nepatření migrantů jsou v občanské sféře situačně zvýznamňovány či upozad'ovány různé kategorie diferencí, jako je etnicita, gender, sociální třída či náboženství, které vykazují různý potenciál pro inkluzi do různých občanských společenství. Každodenní interakce migrantů a nemigrantů zvýznamňují různé kategorie diferencí, jež ustavují ty, kdo patří $\mathrm{k}$ danému společenství, a ty, kdo k němu ne tak docela patř́i. Různě definované odlišnosti jsou připisovány sociálnímu řádu společenství těch „Druhých“, mezi kterými se migrující pohybují.

V procesu migrace dochází nejen $\mathrm{k}$ redefinici migrujícího subjektu jakožto př́íslušníka určité kategorie, ale ani definice členství v rámci určitých představovaných společenství nezůstává statická a mění se pod vlivem současných sociálních procesů, zejména globalizace a rostoucí dynamiky světové mobility. Nemění se jen legálně-formální hranice občanství, ale také symbolické hranice prŕíslušnosti k nejrůznějším imaginárním komunitám. Proměňují se představy a prríběhy o tom, co to znamená patřit do určitého sociální pole, i co to znamená do něj nepatřit: „Řadí se sem také příběhy a představy o vnitřních odlišnostech a hierarchiích, podobně jako o nespravedlnostech, právech a povinnostech jednotlivců či skupin daného prostředí““ (Szaló 2007: 109). Tyto symbolické hranice přináležitosti a nepatření se promítají do sociálního postavení migrantů v nejrůznějších sociálních polích. Různé způsoby nepřináležitosti jsou migranty aktuálně zakoušeny v každodenních situacích - na trhu práce, na úřadech, i při návštěvách v původních domovech -, v nichž se sjednává jejich nerovné sociální postavení vůči plnoprávným členům ústředního společenství. Téma sociálních nerovností v souvislosti s dynamikou inkluze/exkluze migrantů v transnacionální perspektivě je další z klíčových dimenzí, která by si v budoucnosti zasloužila bližší pozornost. 


\section{Poděkování}

Ráda bych poděkovala Lucii Galčanové za pečlivé čtení dřívější verze textu, její cenné komentáře a stylistické úpravy. Za kritické poznámky a návrhy patř́i velký dík také Kateřině Sidiropulu Janků, Ondřeji Hofírkovi a anonymním recenzentům.

\section{Literatura}

AL-ALI, Nadje. Trans-or a-national: Bosnian refugees in the UK and the Netherlands. In KOSER, K., AL-ALI, N. (eds.) New Approaches to Migration?: Transnational Communities and the Transformation of Home. 1. vyd. London: Routledge, 2002, s. 96-117. ISBN 0-41525-432-9.

AL-ALI, Nadje; KOSER, Khalid. New Approaches to Migration?: Transnational Communities and the Transformation of Home. 1. vyd. London: Routledge, 2002. 264 s. ISBN 0-41525-432-9.

ALEXANDER, Jeffrey C. Core Solidarity, Ethnic Outgroup, and Social Differentiation. In Action and its Environments. Towards a New Synthesis. New York: Columbia University Press, 1988. $816 \mathrm{~s}$.

ALEXANDER, Jeffrey C. The Civil Sphere. USA: Oxford University Press, 2006. 816 s. ISBN 0-19516-250-1.

ALEXANDER, Jeffrey C. The Meaningful Construction of Inequality and the Struggles Against It: A ,Strong Program 'Approach to How Social Boundaries Change. Cultural Sociology, 2007, roč. 1, č. 1, s. 23-30. ISSN 1749-9763.

ANTHIAS, Floya. The Concept of ,Social Division' and Theorising Social Stratification: Looking at Ethnicity and Class. Sociology, 2001, roč. 35, č. 4, s. 835-854. ISSN 0038-0385.

ANTHIAS, Floya. Where do I belong?: Narrating collective identity and translocational positionality. Ethnicities, 2002, roč. 2, č. 4, s. 491-514. ISSN 1468-7968.

BARKER, Chris. Slovnik kulturálních studii. Praha: Portál, 2006. 240 s. ISBN 80-7367-099-2.

BARŠA, Pavel. Politická teorie multikulturalismu. Brno: Centrum pro studium demokracie a kultury, 1999. 347 s. ISBN 80-8595-947-X.

BASCH, Linda; GLICK SCHILLER, Nina; SZANTON BLANC, Cristina. Nations Unbound: Transnational Projects, Postcolonial Predicaments, and Deterritorialized Nation-States. 1. vyd. London, New York: Routledge, 1994. 360 s. ISBN 2-88124-630-3.

BECK, Ulrich; SZNAIDER, Natan. Unpacking cosmopolitanism for the social sciences: a research agenda. The British Journal of Sociology, 2006, roč. 57, č. 1, s. 1-23. ISSN $1468-4446$.

BOURDIEU, Pierre. Teorie jednání. 1. vyd. Praha: Karolinum, 1998. 179 s. ISBN 80-7184-518-3.

BRAH, Avtar. Cartographies of Diaspora: Contesting Identities. 1. vyd. Routledge, 1996. 288 s. ISBN 0-41512-126-4.

BRUBAKER, Rogers. Citizenship and Nationhood in France and Germany. London: Harvard University Press, 1992. 272 s. ISBN 0-67413-177-0. 
BRUBAKER, Rogers. Ethnicity without Groups. London: Harvard University Press, 2004. 296 s. ISBN 0-67401-539-8.

BRUBAKER, Rogers. The return of assimilation? Changing perspectives on immigration and its sequels in France, Germany, and the United States. In JOPPKE, C., MORAWSKA, E. (eds.) Toward Assimilation and Citizenship: Immigrants in Liberal Nation-States. Palgrave Macmillan, 2003, s. 39-58. ISBN 1-40390-491-X.

CASTLES, Stephen; DAVIDSON, Alastair. Citizenship \& Migration: Globalization and the Politics of Belonging. 1. vyd. Routledge, 2000. 336 s. ISBN 0-41592-714-5.

CASTLES, Stephen; MILLER, Mark J. The Age of Migration: International Population Movements in the Modern World. 2 vyd. Basingstoke: Macmillan Press, 1998. 336 s. ISBN 1572303824.

COHEN, Jeffrey H. The Culture of Migration in Southern Mexico. University of Texas Press, 2004. 207 s. ISBN 0292705921.

DAVIS, Kathy. Intersectionality as buzzword: A sociology of science perspective on what makes a feminist theory successful. Feminist Theory, 2008, roč. 9, č. 1, s. 67-85. ISSN 1464-7001.

ENGBERSEN, Godfried. Spheres of Integration: Towards a Differentiated and Reflexive Ethnic Minority Policy. In SACKMANN, R., PETERS, B., FAIST, P. (eds.) Identity and Integration: Migrants in Western Europe. Ashgate, 2003, s. 59-77. ISBN 0-75463-211-3.

FAIST, Thomas. The Border-Crossing Expansion of Social Space: Concepts, Questions and Topics. In FAIST, T., ÖZVEREN, E. (eds.) Transnational Social Spaces: Agents, Networks, and Institutions. Aldershot: Ashgate, 2004. s. 1-34. ISBN 0-75463-291-1.

FAIST, Thomas; ÖZVEREN, Eyüp. Transnational Social Spaces: Agents, Networks and Institutions, Ashgate Publishing, 2004. 237 s. ISBN 0-75463-291-1.

FAVELL, Adrian. Integration Nations: The Nation State and Research on Immigrants in Western Europe. In MORAWSKA. E., JOPPKE,C. (eds.) International Migration Research. Constructions, Omissions and the Promises of Interdisciplinarity. Ashgate, 2005, s. 41-69. ISBN 0-75464-219-4.

FOURON, Georges. Haitian Immigrants in the United States. The Imagining of where "home" is in their transnational social fields. In YEOH, B., CHARNEY, M.W., KIONG, T.C. (eds.) Approaching Transnationalisms: Studies on Transnational Societies, Multicultural Contacts, and Imaginings of Home. 1. vyd. Springer, 2003, s. 205-251. ISBN 1402074476.

GIDDENS, Anthony. A Contemporary Critique of Historical Materialism. University of California Pr., 1982. 280 s. ISBN 0-52004-490-8.

GIDDENS, Anthony. The Nation-State and Violence: Volume 2 of A Contemporary Critique of Historical Materialism. University of California Press, 1987. 407 s. ISBN 0-52006-039-3.

HUGO, Graeme. Quantifying Transnationalism: Asian Migration to Australia, keynote paper delivered at the Conference on Migration and Development. University of Ostrava and European Polytechnic Institute, 4-5 September 2007. 
JANKU゚, Kateřina. Rómové a jiní „Téměř-češi”. Pozice kandidátu sociální inkluze do české společnosti. Sociální studia, 2003, č. 10, 115-129 s. ISSN 1214-813X.

JOPPKE, Christian. Exkluze v liberálním státě: případ politiky imigrace a občanství. Sociální studia, 2006, č. 1. 55-72 s. ISSN 1214-813X.

JOPPKE, Christian; MORAWSKA, Ewa. Toward Assimilation and Citizenship: Immigrants in Liberal Nation-States, Palgrave Macmillan, 2003. 256 s. ISBN 1-40390-491-1.

KEARNEY, Michael. The Local and the Global: The Anthropology of Globalization and Transnationalism. Annual Review of Anthropology, 1995, roč. 24, č. 1, s. 547-565. ISSN 0084-6570.

KLVAČOVÁ, Petra. Identita integrace: Vytváření přiběhu úspěšné integrace ve vyprávění cizincu žijících v České republice [disertační práce]. Praha: Fakulta sociálních věd Univerzity Karlovy, 2006.

KLVAČOVÁ, Petra. Uznání cizinců v každodenním životě. In ŠANDEROVÁ, J. (ed.) Nerovnosti kolem nás. Analýza utváření sociálnich nerovností v každodenním životě. 1. vyd. Praha: Tomáš Bitrich, 2006, s. 9-28. ISBN 80-239-8209-5.

LENZ, Ilse. (eds.) Crossing Borders and Shifting Boundaries. Vol. II: Gender, Identities and Networks. Opladen: Leske + Budrich, 2002. ISBN 3-81003-494-0.

LEVITT, Peggy. Keeping Feet in Both Worlds: Transnational Practices and Immigrant Incorporation in the United States. In C. JOPPKE, C., MORAWSKA, E. (eds.) Toward Assimilation and Citizenship: Immigrants in Liberal Nation-States. Palgrave Macmillan, 2003. 256 s. ISBN 1-40390-491-X.

LEVITT, Peggy; GLICK SCHILLER, Nina. Conceptualizing Simultaneity: A Transnational Social Field Perspective on Society. International Migration Review, 2004, roč. 38, č. 3, s. 1002-1039. ISSN 0197-9183.

LEY, David. Transnational spaces and everyday lives. Transactions of the Institute of British Geographers, 2004, roč. 29, č. 2, s. 151-164. ISSN 0020-2754.

LONG, Lynellyn; OXFELD, Ellen. Introduction: An Ethnography of Return. In Coming Home? Refugees, Migrants, and Those Who Stayed Behind. Philadelphia: University of Pennsylvania Press, 2004, s. 1-19. ISBN 0-81221-858-2.

MAHLER, Sarah J. Theoretical and Empirical Contributions Toward a Research Agenda for Transnationalism. In SMITH, M., GUARNIZO, E. (eds.) Transnationalism from below. Transaction Publishers, 1998, s. 64-103. ISBN 1-56000-990-X.

MALKKI, Liisa H. Refugees and Exile: From „Refugee Studies” to the National Order of Things. Annual Review of Anthropology, 1995, roč. 24, s. 495-523. ISSN 0084-6570.

MOROKVASIC, Mirjana. ,Settled in Mobility”: Engendering Post-Wall Migration in Europe. Feminist Review, 2004, roč. 77, č. 1, s. 7-25. ISSN 0141-7789.

MORRIS, Lydia. Managing Contradiction: Civic Stratification and Migrants'rights. International Migration Review, 2003, roč. 37, č. 1, s. 74-100. ISSN 0197-9183.

MUSIL, Jiří. Regionální a místní formy sociálního vyloučení a jak jim čelit - problém vnitřních periferií v České republice. In SIROVÁTKA, T. (ed.) Sociální vyloučení a sociální politika. Brno: Masarykova univerzita, Praha: Výzkumný ústav práce a sociálních věcí, 2006, s. 25-40. ISBN 80-210-4225-7, 80-97007-29-8. 
ONG, Aihwa. Flexible Citizenship: The Cultural Logics of Transnationality. Duke University Press, 1999. 336 s. ISBN 0-82232-269-2.

PENNINX, Rinus. Integration of Migrants: Economic, Social, Cultural and Political Dimensions. Background Paper for the UNECE-conference January 12-14, 2004, Geneva.

PHILLIPS, Anne; SAHARSO, Sawitri. Guest editorial: The rights of women and the crisis of multiculturalism. Ethnicities, 2008, roč. 8, č. 3, s. 291-301. ISSN 1468-7968.

PRIES, Ludger. New Migration in Transnational Spaces. In PRIES, L. (ed.) Migration and Transnational Social Spaces. Aldershot: Ashgate, 1999. s. 1-35.

SACKMANN, Rosemarie c PETERS, Bernhard.; FAIST, Thomas. Identity and Integration. Aldershot: Ashgate. 2003. 260 s. ISBN 0-75463-211-3.

SALIH, Ruba. Shifting Meanings of ,Home': consumption and identity in Moroccan women's transnational practices between Italy and Morocco. In N. AL-ALI, N., KOESR, K. (eds.) New Approaches to Migration? Transnational Communities and the Transformation of Home. UK: Routledge, 2001, s. 51-68. ISBN 0-41525-432-9.

SMITH, Michael; GUARNIZO, Luis. Transnationalism from Below. Transaction Publishers, 1998. 316 s. ISBN 1-56000-990-X.

SMITH, Michael P. Can You Imagine? Transnational Migration and the Globalization of Grassroots Politics. Social Text, 1994, roč. 39, s. 15-33. ISSN 0164-2472.

SMITH, Michael P. Transnational Urbanism: Locating Globalization. Wiley-Blackwell, 2001. 232 s. ISBN 0-63118-424-4.

SOYSAL, Yasemin N. Limits of Citizenship: Migrants and Postnational Membership in Europe. 1. vyd. Chicago: University of Chicago, 1994. 251 s. ISBN 0-22676-842-2.

STRAUSS, Anselm L. Mirrors \& Masks: The Search for Identity. 2. vyd. New Brunswick: Transaction publishers, 1997. $188 \mathrm{~s}$. ISBN 1-56000-935-7.

SZALÓ, Csaba. Domov a jiná místa/ne-místa formování kulturních identit. Sociální studia, 2006, č. 1, s. 145-161. ISSN 1214-813X.

SZALÓ, Csaba. Transnacionální migrace: Proměny identit, hranic a věděni o nich. 1. vyd. Brno: CDK, 2007. 256 s. ISBN 80-7325-136-9.

TOLLAROVÁ, Blanka. Integrace cizinců v Česku: pluralita, nebo asimilace? Biograf, 2006, č. 39. ISSN 1211-5770.

WESTWOOD, Sallie; PHIZACKLEA, Anni. Trans-Nationalism and the Politics of Belonging. 1. vyd. London: Routledge, 2000. 192 s. ISBN 0-41518-980-2.

WIMMER, Andreas; SCHILLER GLICJ, Nina Methodological nationalism and beyond: nation-state building, migration and the social sciences. Global Networks, 2002, roč. 2, č. 4, s. 301-334. ISSN 1470-2266.

\section{Další zdroje}

FEMAGE. Rozhovory v rámci projektu FSS MU FEMAGE. Needs for female Immigrants in Ageing Societies. 2006. 


\section{Autorka}

Radka Klvaňová je doktorandkou na oboru sociologie na Fakultě sociálních studií v Brně, kde zároveň působí v Institutu pro výzkum reprodukce a integrace společnosti. Věnuje se výzkumu migrací, v současné době zejména začleňování migrantů z Běloruska, Ruska a Ukrajiny v transnacionální perspektivě. Vystudovala magisterský program IMPALLA zaměřený na analýzu sociální politiky na univerzitě v belgické Lovani a sociologii na Fakultě sociálních studií MU.

Kontakt: klvanova@fss.muni.cz 